\title{
Information Seeking Behavior of Science Faculty: A Study.
}

\author{
Prof. Mrunal Barki *, Prof. Dr. Deepak Kapade ** \\ ${ }^{1}$ Librarian C. J. Patel College, Tiroda.(MS) \\ ${ }^{2}$ Librarian Kavi Kulgur Kalidas Sanskrit University, Ramtek. (MS)
}

\begin{abstract}
The present paper deals with the information seeking behavior of faculty of Science Colleges of Gondia Education Society, Gondia. The Study conducted through survey and reveals that 52(28.85\%)faculty mostly used the reference sources, Books and Journals. The paper also throws light on the knowledge and use of $e$ - resources, problem in lack of time and satisfaction or faculty for library resources and services.
\end{abstract}

Keywords: Information, Information Seeking Behavior, Gondia Education Society.

\section{Introduction:}

We all need and use Information in our daily lives whether in a Education field society, business development or individual. It exists without saying. We talk about it, we seek it, we exchange it \& we pay for it. Information flows in various ways.. Gondia Education Society is well known and largest education society in Vidarbha region of Maharashtra, providing quality education . The society was established on $8^{\text {th }}$ Dec. 1958. The society was formed by Late Shri Manoharbhai Patel to improve the level of education especially in the region of Bhandara \& Gondia district of Maharashtra. We have select only those colleges which is aided in science faculty \& specially reference with only Biological Science Department.

\section{Definition:}

Information:

Information is sensible statement opinion fact, concept or ideas or an association of statement,"Information could be considered as means to an end but not the end itself."

\section{Information Seeking Behavior:}

Information seeking behavior tend to differentiate between immediate needs the related activities of which are deemed to be "Information - Seeking Behavior ," and deferred needs, which many researchers \& Faculties have termed " Information Gathering “.

\section{Scope And Limitation of The Study:}

The scope of the study is limited to ascertain the information seeking behavior of faculties in Biological department of Gondia education society, Gondia .

We have selected only science colleges among the other colleges in Gondia Education Society. The subject coverage of the study is limited to the subject i.e. Chemistry, Botany, Zoology.

\section{Objectives :}

1. To identify faculties information need.

2. To identify the various channels through which information is accessed by biological faculties.

3. Utilization of different types of library services.

4. To examine the different constrains faced by biological faculties.

5. To identify sources of information they use.

\section{Methodology :}

The study was based on data collected from the biological faculties using a questionnaire and interview method . the questionnaire was structured in two parts. The first part was for collecting the personal data of the faculties and the second part user pattern.

\section{Review of the related literature:}

The literature of information seeking behavior of users is available in wider range. An attempt has been made to cover number of works that go beyond discussions of the information seeking behavior itself and its direct application to closely related topics such as information seeking. This board review also includes topics like information seeking of all types of library users. 
- Chuma Opara Nnadozie and Chizoba Doris Nnadozie (2008) carried out the study information need of faculty members in one of these private tertiary institutions and also looks for a significant difference between the information the information needs of faculty members in private and public Universities.

- T. Prabhkaran, Dr. P. Ravichandan, M.G. Sathiyamurthy and Dr. K. Vijaykumar (2010) investigated the study was based on data collected from the Arts and science teaching community using a questionnaire was distributed personally to each faculty member of the two arts and science colleges.

\section{Data Analysis :}

Analysis of data is the important step in research process. The present study explores the analysis of data gathered through structured questionnaire designed science department of various colleges in Gondia education society, Gondia. The data were analyzed using the Tables. It is observed from the Table no. -1 that majority of biological faculties $15(28 \%)$ in J.M.Patel College, other colleges faculty response 10(19.24\%), 8 ( $15.39 \%), 8(15.39), 10(19.24 \%), 7$ ( 13.47) .

Table No.1 Majority of Biological Faculty

\begin{tabular}{|c|c|c|c|}
\hline Sr.No. & Institute Name & No.Of Respondent & Percentages \\
\hline 1 & M.B.Patel College,Deori. & 10 & $13.47 \%$ \\
\hline 2 & D.B.Science, Gondia. & 10 & $19.24 \%$ \\
\hline 3 & C.J.Patel College, Tirora. & $\mathbf{8}$ & $\mathbf{1 5 . 3 9 \%}$ \\
\hline 4 & S.N. More College, Tumsar & $\mathbf{8}$ & $\mathbf{1 5 . 3 9 \%}$ \\
\hline 5 & J.M.Patel College, Bhandara. & 15 & $\mathbf{2 8 . 0 0 \%}$ \\
\hline 6 & M.B.Patel College, Sakoli. & 10 & $19.24 \%$ \\
\hline
\end{tabular}

Table No.-2 Source of information needs

\begin{tabular}{|c|c|c|}
\hline Source & Respose & Percentage \\
\hline Books & 11 & $22.16 \%$ \\
\hline Periodicals & 8 & $15.39 \%$ \\
\hline Technical Reports & 5 & $9.62 \%$ \\
\hline Thesis / Dessertation & 3 & $5.77 \%$ \\
\hline Reference Books & 15 & $28.85 \%$ \\
\hline Handbook & 3 & $5.77 \%$ \\
\hline $\begin{array}{c}\text { Proceeding of conference/ seminar/ } \\
\text { symposia }\end{array}$ & 5 & $\mathbf{9 . 6 2 \%}$ \\
\hline Index/ abstract & 2 & $3.85 \%$ \\
\hline
\end{tabular}

It is observed from Table no. 2 that the science faculty prepare to scan the information through reference Book(28.85), Books (22.16\%), Periodicals (15.39) fulfill their information needs.

Table No.-3 Utilization of Library services:

\begin{tabular}{|c|c|c|}
\hline Library Services & Response & Percentage \\
\hline Book lending & $\mathbf{8}$ & $15.39 \%$ \\
\hline Book reservation & 4 & $7.70 \%$ \\
\hline Inter library loan & 5 & $9.62 \%$ \\
\hline Reference service & 22 & $42.31 \%$ \\
\hline Current awareness service & 7 & $13.47 \%$ \\
\hline Newspaper clipping service & 6 & $11.54 \%$ \\
\hline
\end{tabular}

Table no. 3The most popular and commonly used library services are Reference Service and Lending services. More than 22(42.31\%) of science faculty utilize reference service and lending service $8(15.39 \%)$.

Table No.-4 Use of electronic information sources

\begin{tabular}{|c|c|c|}
\hline Sources & response & Percentage \\
\hline Search engine & 17 & $32.70 \%$ \\
\hline e- journals & 15 & $28.85 \%$ \\
\hline Web opac & 7 & $13.47 \%$ \\
\hline Online reference source & 13 & $25 \%$ \\
\hline
\end{tabular}

Table No. 4 Thus the maximum number of faculties 17(32.70\%) used the different search engines for searching online information sources and $15(28.85 \%)$ faculties used the e-journals. Less number of faculties used web OPAC's and online reference sources. 
Information Seeking Behavior of Science Faculty: A Study.

Table No.-5 Difficulties faced in access information

\begin{tabular}{|c|c|c|}
\hline Factors & Response & Percentages \\
\hline Lack of time & 21 & $40.39 \%$ \\
\hline Lack of knowledge of information sources & 15 & $\mathbf{2 8 . 8 5 \%}$ \\
\hline Lack of knowledge in use of library staff & 6 & $11.54 \%$ \\
\hline Unfriendly library staff & 5 & $\mathbf{9 . 6 2 \%}$ \\
\hline
\end{tabular}

Table No.5 it can be noted that $40.39 \%$ faculties fail to access information due to lack of time and lack of knowledge in use of library services. While only $12.10 \%$ faculties fail to access information due to lack of knowledge in use of library services and unfriendly library staff. It indicates that due to lack of time faculties are unable to get comprehensive information.

\section{Conclusion :}

The faculties expressed a positive attitude towards the Library. They used the library for their seeking needs. Reference books, Journals and Newspapers are the most used channels in library . Faculties information needs are diverse and they rely heavily on books. The lack of time and lack of knowledge of information sources in a library is a major problem in information seeking.

\section{References:}

[1] Rakshit, A. a. (2001). Information Technology And Agriculture. Yojana , 17.

[2] www.gondia education society.com.

[3] Chopkar, H. a. (2011). Information Seeking Behavior of Research Scholars of Biological Science Department of Dr. Babasaheb Marathwada University : A study. International Journal of Information Dissemination and Technology , 241-243.

[4] Chuma, Opara Nnadozie and Chizoba Doris Nnadozie (2008). The Information needs of faculty members in a Nigerian private University : A self study. Library Philosophy and Practice (e-journal),1-9.

[5] T. Prabhakaran, Dr. P. Ravichandran and Dr. K. Vijaykumar (2010). Information access patterns of faculty in arts and sciences colleges in chidambaram. Library philosophy and practice (e- journal),1-6.

[6] Krikelas, J. (1983) Information seeking behavior: patterns and concepts. Drexel Library Quarterly,5-20 